\title{
PENGARUH PENAMBAHAN TEPUNG KETAN HITAM TERHADAP BISKUIT YANG DIHASILKAN
}

\author{
Dian Susanti, S.TP ${ }^{(1)}$ dan Retti Ninsix, S.TP., MP ${ }^{(2)}$ \\ ${ }^{(1)}$ Alumni Teknologi Pangan Faperta UNISI \\ ${ }^{(2)}$ Dosen Teknologi Pangan Faperta UNISI
}

\begin{abstract}
Abstrak
Penelitian ini bertujuan untuk mengetahui pengaruh substitusi tepung ketan hitam yang tepat untuk dapat menghasilkan biskuit yang bermutu baik. Rancangan percobaan penelitian ini adalah menggunakan Rancangan Acak Lengkap (RAL) dengan 4 perlakuan (A : $100 \%$ tepung ketan hitam dan $0 \%$ tepung terigu), (B: 90 $\%$ tepung ketan hitam dan $10 \%$ tepung terigu), (C: $80 \%$ tepung ketan hitam dan 20 $\%$ tepung terigu), (D: $70 \%$ tepung ketan hitam dan $30 \%$ tepung terigu).

Analisa dilakukan untuk menentukan kadar kadar air, kadar abu, kadar protein dan organoleptik (Warna, aroma, tekstur dan rasa). Basil terbaik biskuit yaitu perlakuan D (substitusi tepung ketan hitam 70\% + tepung terigu 30\%) dengan kadar air 3,1647\%, kadar abu 0,9855, kadar protein 6,2272\%, nilai wama 4,30, aroma 2,60, rasa 3,85 dan tekstur 4,55.
\end{abstract}

Kata kunci : biskuit, tepung ketan hitam, tepung terigu.

\section{PENDAHULUAN}

Salah satu bentuk produk pangan yang banyak diminati anak-anak hingga orang dewasa, mulai dari masyarakat ekonomi bawah sampai atas adalah biskuit. Kecendrungan ini berhubungan dengan gaya hidup dan pola makan masyarakat yang serba berubah sebagai bentuk dampak modemitas kehidupan, sehingga menghendaki berbagai inovasi dan kemudahan dalam memperoleh makanan.

Selain makanan pokok dan sampai saat ini terigu masih merupakan bahan utama di dalam pembuatan biskuit, Indonesia bukan negara pengbasil gandum, untuk mengurangi impor tepung terigu perlu dicari bahan yang dapat digunakan untuk subtitusi terigu.

Tepung ketan hitam merupakan pilihan yang cukup tepat sebagai bahan pengganti terigu dalam pembuatan biskuit, Selain mengandung karbohidrat keuntungan yang bisa diperoleh dari biskuit berbahan baku tepung ketan hitam yaitu tingginya kandungan serat yaitu 3,8 g (Farida, 2008) yang baik untuk kesehatan, selain itu indeks gula dalam beras ketan 55\%. Zat kalsium dan magnesium dalam beras hitam yaitu 837,5 mg dan 129,0 mg (Farida, 2008) bermanfaat bagi pengontrolan tekanan darah dan mengurangi risiko terserang penyakit pembuluh darah otak danjantung (Koswara, 20109)

Berdasarkan penelitian Ardela (2010), di dalam pengolahan brownis kukus selain menggunakan tepung terigu sebagai bahan baku temyata juga memanfaatkan tepung ketan hitam dan tepung kecambah kacang pagar sebagai subtitusi dan hasil brownis terbaik yaitu dengan formulasi tepung 
ketan hitam 80\%, tepung kecambah kacang pagar $20 \%$. Sedangkan pada penelitian Ardiarini (2012) pada pembuatan cake dengan penambahan tepung ketan hitam dan tepung terigu dinyatakan bahwa hasil formulasi terbaik yaitu dengan perlakuan penambahan tepung ketan hiram 100\% dan $0 \%$ tepung terigu.

Berdasarkan uraian tersebut, maka penulis telah melakukan penelitian dengan judul Pengaruh Substitusi Tepung Ketan Hitam (Oryza sativa L var forma glutinosa) terhadap Mutu Biskuit yang Dihasilkan.

Biskuit merupakan produk olahan yang selama ini bahan baku pembuatan biskuit adalah tepung terigu yang terbuat dari gandum, namun sebenarnya bahan baku pembuatan biskuit dapat disubstitusi dengan tepung yang mengandung karbohidrat lainnya salah satunya yaitu tepung ketan hitam.

\section{Tujuan Penelitian}

Tujuan penelitian Pengaruh Substitusi Tepung Ketan Hitam (Oryza sativa $L$ var forma glutinosa) terhadap Mutu Biskuit yang Dihasilkan adalah untuk mendapatkan substitusi tepung ketan hitam yang tepat untuk dapat menghasilkan biskuit yang bermutu baik.

\section{Manfaat Penelitian}

Manfaat dari penelitian "Pengaruh Substitusi Tepung Ketan Hitam (Oryza sativa $L$ var forma glutinosa) terhadap Mutu Biskuit yang Dihasilkan" adalah :

1. Sebagai sumber informasi di dalam pembuatan biskuit yang disubstitusi tepung ketan hitam dengan tepung terigu.

2. Sebagai sumber informasi di dalam pengoptimalan pemanfaatan ketan hitam di dalam pengolahan pangan.

\section{METODOLOGI PENELITIAN}

\section{Bahan dan Alat}

Bahan yang digunakan pada penelitian ini adalah tepung ketan hitam, telur, gula, air bersih, minyak, tepung terigu,soda kue, tissue roll, alumunium foil, dan bahan analisa yaitu $\mathrm{MgCb}, 6 \mathrm{H} 20, \mathrm{NaBr}, \mathrm{NaCl}, \mathrm{KCl}$, dan garam KN03.

Alat yang digunakan pada penelitian ini adalah pisau, toples, panci, blender, kantong plastik, mixer, baskom, pengayakan 80 mesh, talenan, wadah, pengadnk, cetakan, sendok, dan nampang sedangkan alat analitis yaitu timbangan analitik, stopwach, cawan, desikator, pipet, tabung reaksi, dan oven

\section{Metode Penelitian}

Penelitian ini dilakukan dengan menggunakan Rancangan Acak Lengkap (RAL) dengan 4 perlakuan 3 kali ulangan. Adapun Perlakuan yang dilakukan adalah penambahan tepung ketan hitam (Oryza sativa L var forma glutinosa) dan tepung terigu didalam pembuatan biskuit yaitu :

$\mathrm{A}=100 \%$ tepung ketan hitam dan $0 \%$ tepung terigu

$\mathrm{B}=90 \%$ tepung ketan hitam dan $10 \%$ tepung terigu

$\mathrm{C}=80 \%$ tepung ketan hitam dan $20 \%$ tepung terigu

$\mathrm{D}=70 \%$ tepung ketan hitam dan $30 \%$ tepung terigu

\section{HASIL DAN PEMBAHASAN}

\section{Kadar Air}

Kandungan air dalam bahan pangan ikut menentukan tingkat penerimaan, kesegaran dan daya awet produk tersebut. Sebagian besar dari perubahan-perubahan kimia dan 
biokimia pada bahan makanan terjadi dalam media air yang berasal dari bahan itu (Winarno, 1997).

Hasil analisis sidik ragam menunjukkan bahwa substitusi tepung ketan hitam memberikan pengaruh yang berbeda tidak nyata dengan $\mathrm{F}$ hitung $>\mathrm{F}$ tabel terhadap kadar air biskuit yang dihasilkan menurut uji lanjut BNJ pada taraf nyata $5 \%$. Rata-rata kadar air berdasarkan perlakuan substitusi tepung ketan hitam dapat dilihat pada Tabel 1.

Tabel 1. Rata-Rata Kadar Air Biskuit Berdasarkan Perlakuan Substitusi Tepung Ketan Hitam.

\begin{tabular}{|c|c|}
\hline \multicolumn{1}{|c|}{ Perlakuan } & \multicolumn{1}{|c|}{ Kadar Air $(\%)$} \\
\hline A (100\% tepung ketan hitam $+0 \%$ tepung terigu) & 3,7339 \\
B (90\% tepung ketan hitam $+10 \%$ tepung terigu) & 3,4359 \\
C (80\% tepung ketan hitam $+20 \%$ tepung terigu) & 3,2284 \\
D (70\% tepung ketan hitam $+30 \%$ tepung terigu) & 3,1647 \\
\hline
\end{tabular}

Tabel 1 memperlihatkan bahwa kadar air biskuit dengan perlakuan substitusi tepung ketan hitam berkisar antara 3,1647\% - 3,7339\%. Kadar air tertinggi diperoleh dari perlakuan A (100\% tepung ketan hitam $+0 \%$ tepung terigu) yaitu $3,7339 \%$ dan kadar air terendah diperoleh dari perlakuan $\mathrm{D}$ (70\% tepung ketan hitam $+30 \%$ tepung terigu) yaitu $3,1647 \%$. Secara keseluruhan besarnya kadar air yang dikandung oleh biskuit dengan perlakuan A, B, C dan D yaitu perlakuan substitusi tepung ketan hitam 70\%, 80\%, 90\% dan $100 \%$ masih memenuhi persyaratan yang ditetapkan oleh Standar Nasional Indonesia (SNI) yaitu maksimum $5 \%$.

$$
\text { Hasil analisa statistik }
$$

menunjukkan bahwa perlakuan substitusi tepung ketan hitam memberikan pengaruh yang berbeda tidak nyata terhadap kadar air biskuit yang dihasilkan. Semakin besar substitusi tepung ketan hitam yang ditambahkan ke dalam biskuit maka kadar air biskuit yang dihasilkan semakin meningkat walaupun tidak signifikan. Hal ini disebabkan karena tepung ketan hitam mengandung amilopektin yang tinggi yaitu 68.85 $\%$. Amilopektin adalah polimer glukosa yang berhubungan melalui ikatan a-I,4 dan merupakan polisakarida bercabang mengandung rantai bercabang, Amilopektin terdiri atas lebih dari 100.000 unit glukosa. Dalam molekul ini, rantai pendek dari rangkaian glikosida a $\left(\begin{array}{ll}1 & 4\end{array}\right)$ unit glukosa digabungkan dengan rangkaian glikosida lain melalui ikatan glikosida a (1 6) (Winarno, 1997). Amilopektin pada tepung ketan hitam tinggi hal ini menunjukkan sernakin tinggi kadar amilopektin maka semakin tinggi penyerapan air yang ditandai oleh tingginya kadar air. Pada proses gelatinisasi, ikatan hidrogen yang mengatur integritas struktur granula pati akan melemah, Terdapatnya gugus hidroksil yang bebas akan menyerap rnolekul air sehingga terjadi pembengkakan granula pati (Widowati, dkk., 2003). Amilosa mempunyai ikatan intramolekul yang lebih kuat dibandingkan amilopektin sehingga ikatan hidrogen antara molekul 
amilosa dan air lebih sulit terbentuk dibandingkan amilopektin (Winamo, 1997). Hal inilah yang menyebabkan semakin tinggi kandungan amilopektin maka akan semakin tinggi tingkat penyerapan kadar airnya.

\section{Kadar Abu}

Abu adalah zat anorganik sisa hasil pembakaran suatu bahan organik.

Beberapa vitamin dan semua mineral bersifat larut dalam air sehingga dapat terbuang bersama dengan cairan yang digunakan untuk memasak. Pemasakan dengan cara cepat dan menggunakan sedikit atau tanpa air merupakan pilihan tepat untuk mempertahankan vitamin dan mineral. Kandungan abu dalam bahan pangan dan komposisinya tergantung pada macam bahan dan cara pengabuannya. Menurut Fauzi (2006), bahwa kadar abu ada hubungannya dengan mineral suatu bahan. Hasil analisis sidik ragam menunjukkan bahwa substitusi tepung ketan hitam memberikan pengaruh yang berbeda nyata dengan $\mathrm{F}$ hitung F tabel terhadap kadar abu Biskuit yang dihasilkan menurut uji lanjut BNJ pada taraf nyata $5 \%$. Rata-rata kadar abu berdasarkan perlakuan substitusi tepung ketan hitam dapat dilihat pada Tabel 2.

Tabel 2. Rata-rata Kadar Abu Biskuit Berdasarkan Perlakuan Substitusi TepungKetan Hitam

\begin{tabular}{|c|cc|}
\hline Perlakuan & \multicolumn{2}{|c|}{ Kadar Air (\%) } \\
\hline A (100\% tepung ketan hitam + 0\% tepung terigu) & 2,0164 a \\
B (90\% tepung ketan hitam + 10\% tepung terigu) & $1,3317 \quad$ ab \\
C (80\% tepung ketan hitam + 20\% tepung terigu) & $1,0611 \quad \mathrm{~b}$ \\
D (70\% tepung ketan hitam + 30\% tepung terigu) & $0,9855 \quad \mathrm{~b}$ \\
\hline
\end{tabular}

Tabel 2 memperlihatkan bahwa kadar abu biskuit dengan perlakuan substitusi tepung ketan hitam berkisar antara 0,9855\% - 2,0164\%. Kadar abu tertinggi diperoleh dari perlakuan A (100\% tepung ketan hitam $+0 \%$ tepung terigu) yaitu $2,0164 \%$ dan kadar abu terendah diperoleh dari perlakuan D (70\% tepung ketan hitam $+30 \%$ tepung terigu) yaitu $0,9855 \%$. Secara keseluruhan besarnya kadar abu yang dikandung oleh biskuit dengan perlakuan B, C dan D yaitu perlakuan substitusi tepung ketan hitam 70\%, 80\% dan 90\% masih memenuhi persyaratan yang ditetapkan oleh Standar Nasional Indonesia (SNI) yaitu maksimum 1,6\%, kecuali untuk perlakuan A (100\% tepung ketan hitam $+0 \%$ tepung terigu) kadar abunya melebihi SNI.
Hasil analisa statistik menunjukkan bahwa perlakuan substitusi tepung ketan hitam memberikan pengaruh yang berbeda nyata terhadap kadar abu biskuit yang dihasilkan. Perlakuan A (100\% tepung ketan hitam $+0 \%$ tepung terigu) berbeda nyata dengan perlakuan $\mathrm{C}$ (80\% tepung ketan hitam $+20 \%$ tepung terigu) dan $\mathrm{D}$ (70\% tepung ketan hitam $+30 \%$ tepung terigu) tetapi berbeda tidak nyata dengan perlakuan B $(90 \%$ tepung ketan hitam + $10 \%$ tepung terigu). Sedangkan perlakuan B (90\% tepung ketan hitam + $10 \%$ tepung terigu)berbeda tidak nyata dengan C (80\% tepung ketan hitam + $20 \%$ tepung terigu) dan D (70\% tepung ketan hitam $+30 \%$ tepung terigu) Semakin besar substitusi tepung ketan hitarn yang ditambahkan ke dalam 
biskuit maka kadar abu biskuit yang dihasilkan semakin meningkat, Hal ini disebabkan karena tepung ketan hitam menyumbang kadar abu lebih tinggi (Ardiarini, 2012), sehingga jumlahnya pada produk biskuit yang disubstitusi bertambah karena dalam pelaksanaan proses pembuatan tepung ketan hitam belum menerapkan seluruh prinsip higienis sanitasi antara lain proses pengolahan (penjemuran, penggilingan) sehingga mengandung residu anorganik (abu) lebih tinggi (Marwati, 2011).

\section{Kadar Protein}

Protein adalah sumber asamasam amino yang mengandung unsurunsur $\mathrm{C}, \mathrm{H}, \mathrm{O}$ dan $\mathrm{N}$ yang tidak dimiliki oleh lemak atau karbohidrat (Winamo, 1997). Hasil analisis sidik ragam mennnjukkan bahwa substitusi tepung ketan hitam memberikan pengaruh yang berbeda nyata dengan $\mathrm{F}$ hitung 2 : $\mathrm{F}$ tabel terhadap kadar abu biskuit yang dihasilkan menurut uji lanjut BNJ pada taraf nyata $5 \%$. Rata-rata kadar protein berdasarkan perlakuan substitusi tepung ketan hitam dapat dilihat pada Tabel 3.

Tabel 3. Rata-rata Kadar Protein Biskuit Berdasarkan Perlakuan Substitusi Tepung Ketan Hitam

\begin{tabular}{|c|c|}
\hline \multicolumn{1}{|c|}{ Perlakuan } & \multicolumn{2}{|c|}{ Kadar Air (\%) } \\
\hline D (70\% tepung ketan hitam $+30 \%$ tepung terigu) & 6,2272 a \\
C (80\% tepung ketan hitam $+20 \%$ tepung terigu) & 5,0502 ab \\
B (90\% tepung ketan hitam $+10 \%$ tepung terigu) & $3,3957 \quad$ bc \\
A (100\% tepung ketan hitam + 0\% tepung terigu) & $1,9558 \quad \mathrm{c}$ \\
\hline
\end{tabular}

Tabe1 3 memperlihatkan bahwa kadar protein biskuit dengan perlakuan substitusi tepung ketan hitam berkisar antara $1,9558 \%$ - 6,2272\%. Kadar protein tertinggi diperoleh dari perlakuan D (70\% tepung ketan hitam + $30 \%$ tepung terigu) yaitu 6:02272\% dan kadar protein terendah diperoleh dari perlakuan A $(100 \%$ tepung ketan hitam $+0 \%$ tepung terigu) yaitu $1,9558 \%$. Secara keseluruhan besamya kadar protein yang dikandung oleh biskuit dengan perlakuan $\mathrm{A}, \mathrm{B}, \mathrm{C}$ dan D yaitu perlakuan substitusi tepung ketan hiram 70\%, 80\%, 90\% dan $100 \%$ belum memenuhi persyaratan yang ditetapkan oleh Standar Nasional Indonesia (SNI) yaitu minimum $9.0 \%$.

$$
\text { Hasil analisa statistik }
$$

menunjukkan bahwa perlakuan substitusi tepung ketan hitam memberikan pengaruh yang berbeda nyata terbadap kadar abu biskuit yang dihasilkan. Perlakuan A (100\% tepung ketan hitam $+0 \%$ tepung terigu) berbeda nyata dengan perlakuan $\mathrm{C}(80 \%$ tepung ketan hitam $+20 \%$ tepung terigu) dan $\mathrm{D}$ (70\% tepung ketan hitam $+30 \%$ tepung terigu) tetapi berbeda tidak nyata dengan perlakuan B $(90 \%$ tepung ketan hitam $+10 \%$ tepung terigu). Sedangkan perlakuan B $(90 \%$ tepung ketan hitam + $10 \%$ tepung terigu) berbeda nyata dengan $\mathrm{D}$ (70\% tepung ketan hitam + $30 \%$ tepung terigu), tetapi berbeda tidak nyata dengan perlakuan $\mathrm{C}$ (80\% tepung ketan hitam $+20 \%$ tepung terigu). Perlakuan C (80\% tepung ketan hitam + $20 \%$ tepung terigu) dan perlakuan D (70\% tepung ketan hitam $+30 \%$ tepung terigu) berbeda tidak nyata, Semakin besar substitusi tepung ketan hitam yang ditambahkan ke dalam biskuit maka kadar protein biskuit yang dihasilkan semakin menurun. Hal ini disebabkan karena tepung ketan hiram memiliki 
kadar protein yang lebih rendah dibandingkan tepung terigu. Kadar protein tepung ketan hitam adalah 1,8\% (Farida, 2008), sedangkan kadar protein tepung terigu adalah 8,9\% (Nio, 1992 cit Wirdayanti, 2012).

\section{KESIMPULAN DAN SARAN}

\section{Kesimpulan}

Kesimpulan yang diperoleh setelah melakukan penelitian ini adalah berdasarkan analisa kimia, kadar air biskuit yang terendah adalah $3,1647 \%$ terdapat pada perlakuan D, yaitu substitusi tepung ketan hitam $70 \%$ + tepung terigu 30\% sedangkan kadar abu yang terendah adalah 0,9855\% terdapat pada perlakuan D yaitu substitusi tepung ketan hitam $70 \%+$ tepung terigu $30 \%$. Kadar protein tertinggi adalah $6,2272 \%$ terdapat pada perlakuan D yaitu substitusi tepung ketan hitam $70 \%$ + tepung terigu $30 \%$.

Hasil terbaik biskuit yaitu perlakuan D (substitusi tepung ketan hitam $70 \%$ + tepung terigu 30\%) dengan kadar air 3,1647\%, kadar abu O 9855\%,kadar protein 6)272\%, nilai warna 4,30 , aroma 2,60 , rasa 1,85 dan tekstur 4,55.

\section{Saran}

Untuk penelitian selanjutnya, hendaknya dilakukan penelitian biskuit dari jenis tepung yang lain, dan umur simpan perlu diteliti lebih lanjut.

\section{DAFTAR PUSTAKA}

Ardela, F. 2010. Pengaruh Tingkat Perbandingan Tepung Ketan Hitam dengan Tepung Kecambah Kacang Pagar Terhadap Karakteristik Brownies Kukus Yang Dihasilkan, Skripsi. Fakultas Teknologi Pertanian
Universitas Andalas Padang, Tidak Dipublikasikan,

Ardiarini, R.A.W.D. 2012. Pembuatan Aneka Cake dari Tepung Ketan Hitam, Fakultas Teknik Universitas Negeri Yogyakarta.

Assosiation Of Official Analytical Chemist, 2005. Official Method Of Analysis Of The Assosiation Of Offycial Analytical Chemist. Arlington : The Assosiation Of Official Analytical Chemist, inc.

Astawan, M. 2006. Membuat Mie dan Bihun. Penebar Swadaya, Jakarta

Astawan, M., 2004 Kandungan Serat Dan Gizi Pada Roti Ungguli Mie Dan Nasi http.z/www.gizi.net (akses 28 Agustus 2013)

Badan Standar Nasional 1992. SNI Mutu Gula (SNI 07.31411992). Badan Standarisasi Nasional. Jakarta.

BSN. 1992. SNI Mutu dan Cara Uji Biskuit (SNI 01-2973-1992). Badan Standarisasi Nasional. Jakarta.

Deman IM. 1997. Principles of Food Chemistry. 2nd Edition. (Terjernahan : Kimia Makanan, Edisi ke 2, diterjemahkan oleh Kosasih Padmawinata, penerbit ITB Bandung).

Desrosier, N.W. 2008. Teknologi Pengawetan Pangan. Penerjemah M. Muljohardjo. VI-Press, Jakarta.

Dewantari. 2009. Handout Patiseri. SMK N 4 Yogyakarta.

Farida, A., 2008. Patiseri Jilid 1-3. Direktorat Jenderal Manajemen Pendidikan Dasar dan Menengah Departemen Pendidikan Nasional. Jakarta.

Fellows, P. 1. 2004. Food Processing Technology, Principle and 
Practice. 2nd Ed. CRC Press, Subarna. 1996. Formulasi ProdukEngland.

Hamidah, K, S. Purwanti, 2008, Bahan Ajar Patiseri, Fakultas Teknik, Universitas Negeri Yogyakarta. Yogyakarta.

Kartika, B.., P. Hastuti dan W. Supartono, 1988. Pedoman Uji Inderawi Bahan Pangan. P AU Pangan dan Gizi UGM. Yogyakarta.

Koswara, S. 2009. Teknologi Pengolahan Beras (Teori dan Praktek). Produksi eBookPangan. Com. Akses Tanggal 22 Oktober 2012, Tembilahan.

Mariana, L., 2007. Pembuatan Roti Manis. Diklat Pengolahan Serealia dan Kacang ..Kacangan. Departemen Agroindustri Vedca.P4TK Cianjur, Jawa Barat

Marwati, 2011. Pembuatan Tepung Ubi Jalar. http://epetani. deptan.gojd/. Akses Tanggal22 Oktober 2012, Tembilahan.

Matz, S. A. 1991. Bakery Technology and Engineering. The AVI Publishing Co. Inc. Westport, Connectitut.Hal.13 - 17.

Mudjajanto dan Yulianti. 2004. Membuat Aneka Ron, Jakarta: Penebar Swadaya,

SNI 01-3751-1995, Stan dar Nasional Indonesia. Peraturan Teknis Tepung Terigu. Departemen Perindustrian dan Perdagangan. Jakarta.

produk Serealia dan Umbiumbian Untuk Produk Ekstrusi, Bakery, dan Penggorengan. Makalah. Pelatihan Produkproduk Olahan, Ekstrusi, Bakery, dan Frying, Jakarta.

Sudarmadji, S. Haryono dan Suhardi. 1997. Prosedur Analisa Untuk Bahan Makanan dan Pertanian. Liberty. Yogyakarta.

Tarwotjo, S., 2008. Dasar-Dasar Gizi Kuliner. Gramedia Widiasarana, Jakarta.

Utami, 1.S., 1999. Bahan Ajar Pengolahan Roti. Pusat Antar Universitas Pangan dan Gizi Universitas Gadjah Mada, Yogyakarta.

Wahyudi, 2003. Memproduksi Roti. Direktorat Pendidikan Menengah Kejuruan Direktorat Jenderal Pendidikan Dasar Dan Menengah Departemen Pendidikan Nasional. Jakarta.

Widowati, S., Suismono, Suarni, Sutrisno, dan O. Komalasari. 2003. Petunjuk Teknis Proses Pembuatan Aneka Tepung dari Bahan Pang an Sumber Karbohidrat Lokal, Balai Penelitian Pascapanen Pertanian, Jakarta.

Winamo, F. G. 1997. Kimia Pagan Gizi. Penerbit PT Gramedia Utama. Jakarta. 